\title{
Gross Violation of Human Rights in Aceh: Patterns of Violence through the Indonesian Government's Policy
}

\author{
Dahniar $^{1}$, Adwani $^{2}$, Mujibussalim ${ }^{3}$, Mahfud $^{4}$ \\ ${ }^{I}$ PhD Student at Faculty of Law Syiah Kuala University, \\ ${ }^{2}$ Main Supervisor Syiah Kuala University, \\ ${ }^{3}$ Supervisor Syiah Kuala University, \\ ${ }^{4}$ Supervisor Syiah Kuala University, Indonesia.
}

\begin{abstract}
The purpose of this study is to evaluate the extent to which of the practice of the state's responsibility for the settlement of gross violation of human rights in Aceh (Indonesia). In many ways, human rights in Aceh are being violated, people are individually and as groups repressed and intimidated, and there is the situation of impunity. Since 1976-2005, Indonesia annexed Aceh at gunpoint while the UN watched silently, while the people of Aceh have been denied their basic human rights, including the rights self-determination. During non-international armed conflict between the Free Aceh Movement and the Soldiers of the Republic of Indonesia (1989-2005), the National Commission of Human Rights had concluded, that there has been found internationally wrongful acts of violence perpetrated by the military (state violence), and there were 7,727 cases. The Indonesia Government just kept silent, it showed his unwillingness and unable to implementing state responsibility principle as responsibility to protect as affirmed in Article 17 paragraphs 2 and 3 of the Rome Statute of the International Criminal Court, including neglected Article 2 of the International Covenant on Civil and Political Rights. The result of the Indonesia government's policy has created the genocide and crimes against humanity in Aceh, and the perpetrators of violations are not held accountable or brought to court.
\end{abstract}

Keywords: Gross Violation of Human Rights, Non International Armed Conflict in Aceh, Indonesia Government's Policy, State Responsibility, Responsibility to Protect, International Criminal Court.

\section{INTRODUCTION}

In international discourse, human rights violations, especially seen as the responsibility of the state, in the context of its obligations to citizens. Various experts who support this opinion, states that: human rights violations committed by the state through its agents the state through its agencies (Police, Armed Forces and any person acting with the authority of the state) against the individual. The failure of one state or other parties legally obligated legally obliged to adhere to the norms/rules of international human rights. Failure to perform the obligation is a breach of that obligation. Violation 'is used interchangeably with the term Breach (violations of laws, rules, obligations, agreements) on the obligation.

Many laws in Indonesia are not in line with the Family Principle, these principle is still a mere illusion. The family principle should not only be written in the constitution, but it also has to be understood by every component of the state. While, the Unitary State of the Republic of Indonesia stated that this country is a law based country law-Rechtstaat, and not authoritarian country-Machtstaat, which means that there is no impunity to both institution and person toward national law and international treaty for general criminal violation including gross violation of human rights categorized crime of genocide and crimes against humanity. It can found also in Justice and civilized humanity principle. This principle comprises ambition related to humanity based on the human nature related to humanity or all the people have a strong will to actualize egalitarian, in accordance with values of humanity, especially those related to basic human rights. Justice and civilized are moral values of Indonesia peoples, which becomes a reference in preparing new regulation. Law and moral are two integrated entities: the law should values morality, and morality should be regulated by law (Manan, 2005, p.23), considering justice is a moral concept; who have connection between law and morality; and moral is one of the primary sides of human life, so law is nothing without morality or lex iniusta non-est lex or an unjust law is not a law (Alasdair McIntyre, 1984, p.152)

In the preamble of the Law of the Republic of Indonesia, number 39 of 1999, provided that the nation of Indonesia as a member of the United Nations to assume moral and legal responsibility to uphold a high and carry out the Universal Declaration of Human Rights established by the United Nations and various other international instrument which have been accepted by the Republic of Indonesia. The same thing can found also in Part I of Law of the Republic of Indonesia, number 26 of 2000 of the Human Right Court. 
Concerning the status of the relationship between international and domestic law, the first we should to know, that in the general theory of science, the "unity of normative knowledge" has to be postulated in order to avoid the logical contradictions arising from the acceptance of conflicting criteria for science. This follows in as far as legal science is understood as a system and not merely as a collection of rules of conduct whose normative status has not been questioned. According to this postulate that only one normative system may be presupposed as valid at a given time. The simultaneous acceptance of different normative systems would lead to logical contradictions, amounting to the invalidation of legal science (Hans Kelsen,1960,p.108). We must therefore recognize a fundamental axiom of normative knowledge to be the following: the different existing normative systems (which can be assigned to different areas of social interaction) are to an extent "regional" systems whose contents belong to one universal system (Hans Köchler,1980, p.1)

According to what have said above, the substantive (or material) absence of contradiction between norms is a consequence of the requirement of the absence of epistemological contradiction; it relates to the theoretical (descriptive) understanding of the norms in the formal sense. A "monistic" construction is the only possible formulation of the relationship of normative systems among themselves in terms of legal theory. A system (in the strictest sense of the word) can therefore only be understood as the sum of the universal norms which are implied in all subsystems, i.e. on which the validity of the systems is founded.

Responsibility to protect human rights resides first and foremost with the states themselves. However, in many cases public authorities and government officials institute policies that violate basic human rights, especially gross violation of human rights in Aceh, Indonesia, while in another side, the United Nations watched silently. Such abuses of power by political leaders and state authorities have devastating effects, including genocide, war crimes and crimes against humanity. What can be done to safeguard human rights when those in power are responsible for human rights violations? Can outside forces intervene in order to protect human rights?

Aims of the study were: to compare the mechanism of settlement of cases of gross violations of human rights in the practice of the international law, and to evaluated the extent to which of the practice of the state's responsibility for the settlement of gross violation of human rights in non-international armed conflict in Aceh.

The authors initiated this research used prescriptive analysis method with normative legal research or normative approached, i.e. a research which refers to principles, norms of national and international laws, such as international conventions, charter, united nations resolutions, documents, treaties, cases (case before the ICTY, ICTR, ICC and other mixed or internationalized courts, statutes, court decisions, rules of procedure and evidence. Data were analyzed using qualitative method.

On the basis of this analysis, the authors like to attempt a reformulation of the relationship between these two normative systems in terms of legal theory: The principles of human rights are to be understood as the "common third-through the concept of the third eye" (Dahniar,2016,p.37) to which both of international law and domestic law are assigned.

\section{REVIEW OF RELATED LITERATURE}

\section{Human Rights in International Law}

Human rights are the basic rights and freedoms to which all humans are considered entitled: the right to life, liberty, freedom of thought and expression, and equal treatment before the law, among others. These rights represent entitlements of the individual or groups vis-B-vis the government, as well as responsibilities of the individual and the government authorities. Such rights are ascribed "naturally," which means that they are not earned and can't be denied on the basis of race, creed, ethnicity or gender (Little, David, 2013). These rights are often advanced as legal rights and protected by the rule of law. However, they are distinct from and prior to law, and can be used as standards for formulating or criticizing both local and international law. It is typically thought that the conduct of governments and military forces must comply with these standards.

Various "basic" rights that can't be violated under any circumstances are set forth in international human rights documents such as the Universal Declaration of Human Rights, the International Covenant on Economic, Social and Cultural Rights, and the International Covenant on Civil and Political Rights. The rights established by these documents include economic, social, cultural, political and civil rights.

While human rights are not always interpreted similarly across societies, these norms nonetheless form a common human rights vocabulary in which the claims of various cultures can be articulated. The widespread ratification of international human rights agreements such as those listed above is taken as evidence that these are widely shared values (At the same time, some would argue that the hegemonic power of the West, whether through normative pressure or economic, is responsible for widespread ratification). Having human rights norms in place imposes certain requirements on governments and legitimizes the complaints of individuals in those cases where fundamental rights and freedoms are not respected (Antonio Cassese, 1990, p.2). Such norms constitute a standard for the conduct of government and the administration of force. They can be used as 
"universal, non-discriminatory standards" for formulating or criticizing law and act as guidelines for proper conduct (Little, David, 2013).

Don Hubert and Thomas G. Weiss et al, (IDRC, 2001, p.144) state that international human rights law humanitarian intervention law and refugee law all protect the right to life and physical integrity and attempt to limit the unrestrained power of the state. These laws aim to preserve humanity and protect against anything that challenges people's health, economic well-being, social stability and political peace. Underlying such laws is the principle of nondiscrimination, the notion that rights apply universally.

Many conflicts are sparked by a failure to protect human rights, and the trauma that results from severe human rights violations often leads to new human rights violations. As conflict intensifies, hatred accumulates and makes restoration of peace more difficult. In order to stop this cycle of violence, states must institute policies aimed at human rights protection. Many believe that the protection of human rights "is essential to the sustainable achievement of the three agreed global priorities of peace, development and democracy."(the United Nations, 2000). Respect for human rights has therefore become an integral part of international law and foreign policy. The specific goal of expanding such rights is to "increase safeguards for the dignity of the person." (Antonio Cassese, 1990, p.3), at the same time, The United Nations has created a global structure for protecting human rights, based largely on its Charter, non-binding declarations, legally binding treaties and on various activities aimed at advancing democracy and human rights throughout the world.

The UN's system of human rights protection has three main components: first, it establishes international standards through its Charter, legally binding treaties, non-binding declarations, agreements, and documents; next, it mandates Special Rapporteurs and experts, and groups, such as working groups, committees and treaty bodies, to work in various manners for the promotion and protection of human rights; finally, it offers technical assistance through the Voluntary Fund for Advisory Services and Technical Assistance in the field of Human Rights.

As we know, that the United Nations is composed of six major bodies: the General Assembly, the Secretariat, the Security Council, the International Court of Justice, the Trusteeship Council and the Economic and Social Council. Although the United Nations was divided into these six spheres, they are of unequal size (some possess many subsidiary bodies and committees while others have very few), status (some are quite powerful while others have become almost obsolete), and relevance to human rights (some focus extensively on the issue while others bear little or no relevance for the protection and promotion of human rights).

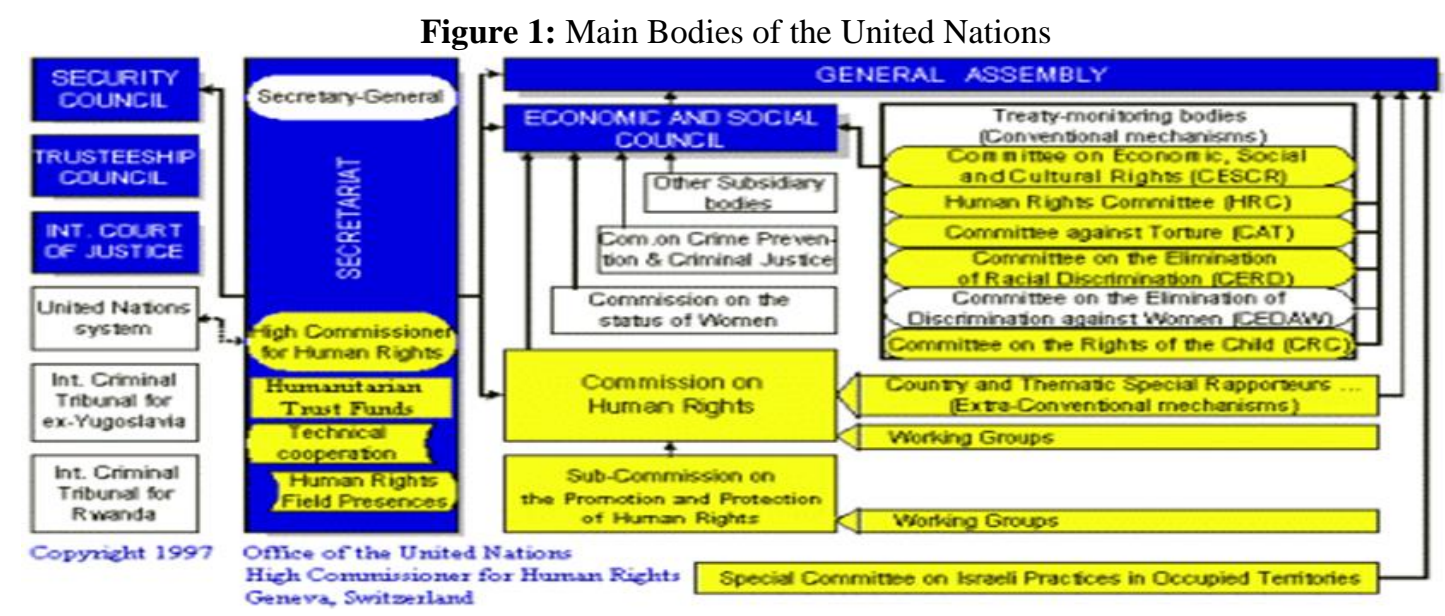

Despite what resembles a widespread consensus on the importance of human rights and the expansion of international treaties on such matters, the protection of human rights still often leaves much to be desired. Although international organizations have been created or utilized to embody these values, there is little to enforce the commitments states have made to human rights. Although not to be dismissed as insignificant, often the only consequence for failing to protect human rights is "naming and shaming."

\section{Definitions of Gross Violation of Human Rights}

In order to determine rules of general validity, or to contribute to their establishment, one must start by seeking a definition of "gross violations of human rights and fundamental freedoms". It appears that the distinction between "simple" and "gross" violations of human rights rests both on the nature and the scope of the violation. In itself, the adjective "gross" in legal jargon indicates conspicuous gravity: a violation is "gross" if it is "out of all measure, flagrant ...conduct ... not to be excused" (Black's Law Dictionary, 5 ed., St. Paul: West, 1979). 
According to A. Dormenyal (1998, p.58) "It still remains to be determined whether any violation of an important human right is "gross", or whether the judgment must be made in every individual case, including the possibility that the violation of any human right could under particular circumstances become gross because of the methods employed"

Schmid, A.P (1989, p.6) state that some commentators seem to limit their consideration to only the violations of some rights and freedoms that they consider to be fundamental and elementary. Thus an important research on gross violations is based on the assumption that only violations of rights proclaimed in articles 3,5 and 9 of the Universal Declaration of Human Rights (rights to life, liberty and security of person, prohibition of torture or cruel, inhuman and degrading treatment and punishment and of arbitrary arrest, detention and exile) can form the basis of gross violations.

E.G. Orentlicher, D.F (1991,pp. 2561, 2568) "Other authors imply a gradation of human rights by using expressions such as "atrocious" or "serious violations of physical integrity".

Bayefsky F. Anne \& John Fitpatrick, 2000, p.167-168) “Gross violation(s) of human rights: a term used but not well defined in human rights resolutions, declarations, and treaties but generally meaning sistematic violations of certain human rights norms of a more serious nature, such as apartheid, racial discrimination, murder, slavery, genocide, religious persecutions on the massive scale, commited as a matter of official practice, Gross violations result in irreparable harm to victim"

Indonesia appears to accept a broader perspective that, as seen from the definition of human rights violations are provided by Law number 39 of 1999 compare the definition by definition a crime, namely: 'The act of crime (criminal) is an action or actions performed by one or more people who are hurt or damage the public and has been banned by the domestic law of the country. Human rights violations in Indonesia Commission Violation of human rights is every act of a person or group of people, including state officials both intentional and unintentional or omission in contravention of legal rights, reduce, impede, restrict, and human rights or deprive a person or group of people guaranteed by this Act, and do not get, or feared would not obtain a fair settlement of legal and correct, based on the existing legal mechanisms of political and social that can't be sorted out, mutually interrelated and interdependent is also aimed at the responsibility of various private actors, not just the state.

\section{DISCUSSION}

\section{Patterns of Violence through the Government's Policy}

The situation becomes more difficult when a regime, which was institutionally based on lawlessness and arbitrariness or had a constitutional and legal system that did not even pretend to be "human rights friendly", is removed. What happened under it was technically not contrary to internal law and international law applied only indirectly. The answers given can either be that persons under the jurisdiction of the state benefitted even then from the general provisions of international human rights law (for it is unlikely that such regimes would have entered into any kind of treaty obligations), or that the fictional "law" of the previous regime (including provisions of treaties for the protection of human rights, hypocritically ratified to enhance its international respectability) could be reinterpreted to cover at least some violations (e.g., provisions on murder extended to genocide, crimes against humanity, war crimes, disappearances, etc.).

In United Nations parlance, the term was for the first time included in the ECOSOC Resolution 1235 (XLII) of 6 June 1967 (UN Doc. E/4393 (1967) to enable the Commission on Human Rights and its Subcommission on Prevention of Discrimination and Protection of Minorities (in the further text: Sub-commission) to examine complaints on violations of human rights piling up in the UN Secretariat. In this resolution, the term is not defined, but the examples provided point in an interesting direction: "...as exemplified by the policy of apartheid as practiced in the Republic of South Africa and in the Territory of South West Africa ... now illegally occupied by the Government of the Republic of South Africa and to racial discrimination practiced notably in Southern Rhodesia..."

Such examples indicate that gross violations are not only repugnant acts, but that they are large-scale and committed as a matter of policy. Conceivably, systematic discrimination may not involve most heinous deeds, but it is still considered a gross violation, because the government and the state are identified with it and it affects many human beings.

The language of the ECOSOC Resolution 1503 (XLVIII) of 27 May 1970 (UN Doc. E/4832/Add. 1(1970), whereby this body established a procedure to deal with communications described in Resolution 1235 (XLII), is illuminating. In its paragraph 1, it refers to a "consistent pattern of gross and reliably attested violations of human rights and fundamental freedoms". Here, there is an even stronger stress on systematic behavior of the government, "consistent pattern" implying not only large numbers but also repetition.

Another case, it can found also in the Velásquez Rodrígues Case, the Inter-American Court of Human Rights found that the government of Honduras was responsible for violations of the American Convention on Human Rights regarding a case of torture and disappearance, and that this responsibility persisted in spite of the 
change of government: "According to the principle of the continuity of the State in international law, responsibility exists both independently of changes of government over a period of time and continuously from the time of the act that creates responsibility to the time when the act is declared illegal. The foregoing is also valid in the area of human rights although, from an ethical or political point of view, the attitude of the new government may be much more respectful of those rights than that of the government in power when the violations occurred.” (Inter-America Court of Human Rights, Ser. C, No. 4 (1988), paragraph 184)

It is undisputable that this view correctly presents the international continuity of the state as to its international responsibility, but the judgment is not clear as to the nature of the obligation of the present government to remedy the failure of the previous regime to "prevent, investigate and punish any violation of the rights recognized by the Convention" (paragraph 176). Does it involve the duty to criminally prosecute in all cases? Although there was an apparent disposition in the Inter-American Commission of Human Rights to allow the national governments to judge the appropriateness of amnesty laws, this was contradicted by a very strong statement to the contrary by its Chairman (Quoted in E.G. Orentlicher, 1991, p. 2579)

The Commission found that Uruguay violated Article 8.1 of the Inter-American Convention on Human Rights because it had impeded the petitioners from exercising their right to be heard by a tribunal in criminal, civil, labour and fiscal matters, Article 25.1 of the Convention, for not guaranteeing the right to recourse against violations of fundamental rights, and Article 1.1 of the Convention, which obligates states parties to respect the rights and liberties in the Convention in order to guarantee their free and open exercise to every person subject to the state party's jurisdiction. The last finding was based on the interpretation of Article 1.1 by the InterAmerican Court in the Velasquez Rodriguez case, where the judges found that the obligations under Article 1.1 encompassed, among other things, a duty to investigate alleged human rights violations with the purpose of imposing pertinent penalties upon those responsible.

In the Preliminary Report to the Sub-commission (UN Doc. E/CN.4/Sub.2/1990/10, paragraph 38), Th. van Boven, provides, that $\mathrm{s}$ state violates international law if it practices, encourages or condones the enumerated violations of human rights "as a matter of state policy". However, this definition becomes somewhat circular when, in addition to distinctive delict, such as genocide, slavery and torture, the vague group of "a consistent pattern of violations of internationally recognized human rights" is included. This may cause us to believe two things: that there is a policy within a policy and that all internationally recognized where human rights could be violated in such a way that they become violations of customary international law and make the state internationally responsible. This is, however, only a solution at the international, inter-state level.

In principle, victims of former gross violations are entitled to remedy, but the government is to decide whether it would be at the expense of public funds or individual violators. Social and health insurance should be restituted to those who lost it in violation of their rights or suffered damage as a result of violations of human rights. Victims of discrimination should not only be protected in the future, but restitution must be attempted to enable them to hold positions which they lost because of belonging to groups discriminated against.

All the arguments set forth so far relate to the international responsibility of the state for violations of human rights. International responsibility results in obligations vis-a-vis other states, where a distinction is to be made between responsibility stemming from violations of duties based on treaty or on customary law. In matters related to human rights, duties have been interpreted to be erga omnes, but the problem still remains how to translate an international obligation into an obligation to private individuals, victims of violations of their human rights.

There are many other fields, still to be discovered, where the results of former violations linger. However, the theme of the punishment of the violators is possibly the most sensitive one. If punishment is viewed as a prevention of future violations, it enters into the wider scope of remedies; if it tends to be coloured by retribution, serious doubts arise, not only in moral terms, but also in terms of feasibility and possibility to generate new conflicts. It is therefore a matter for the democratic government to decide, provided it generally respects human rights. However, if a violation of human rights amounts to a crime under international law, there is a duty to prosecute, even if the act was isolated and thus did not have the systematic and quantitative dimensions of a "gross" violation.

\section{Crimes within the Jurisdiction of the International Criminal Court}

Concerning the crimes within the jurisdiction of the international criminal court, it can found in Part II, Articles 5-10. Article 5 Paragraph of Rome Statute of the International Criminal Court, state that the jurisdiction of the Court shall be limited to the most serious crimes of concern to the international community as a whole. The Court has jurisdiction in accordance with this Statute with respect to the crime of genocide; crimes against humanity; war crimes; and the crime of aggression.

Crimes listed in Article 5(1) of the Rome Statute of the International Criminal Court as a "core crimes as such, or international crimes, and these crimes having risen to the level of jus cogens. It should be noted however that although all norms of jus cogens are enforceable erga omnes not all erga omnes obligations are jus 
cogens (ICJ Reports, 1949, p.185), for example in the Nuclear Test Case, (IJC Reports, 1974), such as Nuclear Test Case (Australia v. France), Judgment of 20 December 1974 (ICJ Reports, 1974, p.253, Para.50 and Nuclear Test Case (New Zealand v. France), Judgment of 20 December 1974 (ICJ Reports, 1974, p. 457, Para. 52). Specific examples of jus cogens based on Articles 1 and 2 of the Charter of the United Nations, included were: (1) Principles of the Charter of the United Nations prohibiting the unlawful use of force (Articles 2.4 and 2.6; (2) International laws that prohibit the performance of any other act criminal under international law; and (3) International laws that oblige States to co-operate in the suppression of certain acts such as trade in slaves, piracy or genocide (J-P Cot, and A. Pellet, 1985, p. 54).

The term "international crimes" was enshrined in International Law Commission's Article 19 of Part I of the 1976 version of the Draft Articles of State Responsibility (Yearbook of the ILC, 1976, Part.2, at 75) in contradistinction to International delicts. Both international crimes and international delicts were supposed to refer to an international wrongful act breaching an international obligation "so essential for the protection of fundamental interests of the international community that its breach is recognized as a crime by that community as a whole" (Article 19(3) of Part 1 of ILC's 1976).

International legal norms prohibiting genocide, in contrast, benefit from the fact that they derive from a single multilateral treaty, namely the Convention on the Prevention and Punishment of the Crime of Genocide, adopted unanimously 9 December 1948, entered into force 12 January 1951; 78 UNTS 277. This convention drafted by the international community with considerable care and precision for the purposes of criminal prosecution by domestic courts or an international tribunal or court.

In the regulation of the Republic of Indonesia, concerning the genocide and crimes against humanity affirmed in Article 7 of the Law No. 26 of 2000 of the Human Rights Court. Both these crimes replicating word for the definition part of Article II of the Genocide Convention, 1948, or Articles 6 and 7 of the Rome Statute of the International Criminal Court, 1998, found also in Articles 4 and 2 of the Statutes for the International Criminal Tribunals for the Former Yugoslavia and Rwanda, respectively. These crimes considered one of the "core crimes".

\subsection{Article 6: Genocide}

Genocide is the principal, and recent, exception to the rule of national implementation. It is now generally accepted that multilateral armed intervention against genocide is permitted if authorized by the Security Council. Genocide thus has been removed from the sphere of sovereign prerogative. To the extent that enforcement authority has been transferred to the society of states, we can even speak of a (tiny) loss of sovereignty. The right of states to commit genocide has suffered the same fate as the right of states to wage aggressive war with no broader implications for sovereignty.

Article 6 provides that 'genocide' means any of the following acts committed with intent to destroy, in whole or in part, a national, ethnical, racial, or religious group, as such:

a) Killing members of the group;

b) Causing serious bodily or mental harm to members of the group;

c) Deliberately inflicting on the group conditions of life calculated to bring about its physical destruction in whole or in part;

d) Imposing measures intended to prevent births within the group;

e) Forcibly transferring children of the group to another group.

In United Nations Resolution number 96, state that "genocide is a denial of the right of existence of entire human groups, as homicide is the denial of the right to live of individual human beings; such denial of the right of existence shocks the conscience of mankind, results in great losses to humanity in the form of cultural and other contributions represented by these human groups, and is contrary to moral law and to the spirit and aims of the United Nations.

\subsection{Article 7: Crimes against humanity}

Article 7 Para. (1) of the Rome Statute lists the acts which come within the legal definition of 'crimes against humanity', and Article 7 Para. (2) sets out definitions of key terms to guide the Court's adjudication on any crime against humanity. The general scope of application and the issue of the threshold to be reached before the Court can seize jurisdiction with respect to crimes against humanity, are addressed in the chapeau to Article 7 Para. (1).

Article 7 Paragraph 1, provides that 'For the purposes of this Statute 'crimes against humanity' means any of the following acts when committed as part of a widespread or systematic attack directed against any civilian population, with knowledge of the attack: and then lists:

(a) Murder;

(b) Extermination;

(c) Enslavement; 
(d) Deportation or forcible transfer of population;

(e) Imprisonment or other severe deprivation of physical liberty in violation of fundamental rules of international law;

(f) Torture,

(g) Rape, sexual slavery, enforced prostitution, forced pregnancy, enforced sterilization, or any other form of sexual violence of comparable gravity;

(h) Persecution against any identifiable group or collectivity on political, racial, national, ethnic, cultural, religious, gender as defined in paragraph 3, or other grounds that are universally recognized as impermissible under international law, in connection with any act referred to in this paragraph or any crime within the jurisdiction of the Court;

(i) Enforced disappearance of persons;

(j) The crime of apartheid;

(k) Other inhumane acts of a similar character intentionally causing great suffering, or serious injury to body or to mental or physical health"

The phrase 'For the purposes of this Statute' disconnects, or at least dissociates, the Statute's definition of 'crimes against humanity' from other definitions of the term that have been used in the past, may currently be in use, or may be developed in future, in contexts not directly related to the operation of the International Criminal Court. This approach allows the Court to apply the term 'crimes against humanity' in ways that reflect the more contemporary expression of the will of the international community as manifested at the Rome Conference, rather than to become encumbered with either its very unclear and confused Nuremberg Charter formulation, or its unreasonably narrow construction in the Security Council's Statute of the International Criminal Tribunal for the Former Yugoslavia.

Paragraphs (a-f), (h-i) and (k) of Article 7 Para.(1) may be conveniently treated together as these provisions follow closely those of Article 6(c) of the Nuremberg Charter, 1945, which for the first time, provided an international law definition of 'crimes against humanity'. The Charter's Article 6(c) lists 'murder, extermination, enslavement, deportation and other inhumane acts committed against any civilian population before or during the war, or persecutions on political, racial, or religious grounds'. Articles 5 and 3 of the Statutes of the International Criminal Tribunals for the Former Yugoslavia and Rwanda, respectively define 'crimes against humanity' by repeating the Nuremberg and Tokyo Charter definitions.

Article 5 of the Statute of the ICTY, provides that "The international tribunal shall have the power to prosecute persons responsible for the following crimes when committed in armed conflict, whether international or internal in character, and directed against any civilian population: murder; extermination; enslavement; deportation; imprisonment; torture; rape; persecutions on political, racial, and religious ground; other inhumane acts"

Article 3 of the Statute of the ICTR, provides that the International Tribunal for Rwanda shall have the power to prosecute persons responsible for the following crimes when committed as part of a widespread or systematic attack against any civilian population on national, political, etnic, racial or religious grounds: murder; extermination; enslavement; deportation; imprisonment; torture; rape; persecution on political, racial and religious grounds; other inhumane acts"

The Article 7 Para.(1) chapeau limits the application of 'crimes against humanity' in three main ways. First, a crime against humanity is not deemed to come within the jurisdiction of the Court unless it were committed 'as part of a widespread or systematic attack'. In other words, a case of murder, to take an example, will not qualify as a crime against humanity unless it was perpetrated in the context of an attack that is 'widespread' i.e. that involves a certain number of persons or involves its commission over a wide territorial area. Alternatively, a crime against humanity may be committed if it formed part of a 'systematic' attack i.e. one that involved planning and organization; Second, the act will not qualify as a crime against humanity unless, in addition to its being committed as part of a widespread or systematic attack, the attack was directed against a civilian population. Article 7 Para.(2) sub Para.(a) provides that 'Attack against any civilian population' means a course of conduct involving the multiple commission of acts referred to or against any civilian population, pursuant to or in furtherance of a state or organizational policy to commit such attack". Third, the acts must also have been committed 'with knowledge of the attack'. This raises two subsidiary issues: what level of 'knowledge of the attack' does the alleged perpetrator have to have had before his or her act may be deemed to have been perpetrated 'pursuant to or in furtherance of a State or organizational policy to commit such attack'? and as an evidentiary matter, does the Prosecutor have to prove actual knowledge on the part of the alleged offender that an attack had occurred, was occurring or was planned to occur, or something less?

For an overview of the early development of the legal category of 'crimes against humanity' and its relation to 'war crimes' as incorporated in the Nuremberg Charter, (Lyal. S. Sunga, 1992), found also in Chapter II (4) and (5) (Ch. Bassiouni, 1992) 


\subsection{Article 8: War Crimes}

Article 8 Para.(1) delimits the entire application of Article 8, much in the same way as do the chapeaux in Articles 6 and 7, by establishing certain threshold criteria before the Court can seize jurisdiction. Article 8(1) provides that 'The Court shall have jurisdiction in respect of war crimes in particular when committed as part of a plan or policy or as part of a large-scale commission of such crimes'. The phrase 'in particular when committed as a part of a plan or policy' implies that the Court shall assume jurisdiction only over cases involving a certain level of organization and command responsibility in fact (not necessarily related to a State).

Article 8 Para.(2) Sub Para.(a), provides that for the purpose of this Statute, 'war crimes' means grave breaches of the Geneva Conventions of 12 August 1949, namely, any of the following acts against persons or property protected under the provisions of the relevant Geneva Convention, namely, Wilful killing; Torture or inhuman treatment, including biological experiments; Wilfully causing great suffering, or serious injury to body or health; Extensive destruction and appropriation of property not justified by military necessity and carried out unlawfully and wantonly; Compelling a prisoner of war or other protected person to serve in the forces of a hostile Power; Wilfully depriving a prisoner of war or other protected person of the rights of fair and regular trial; Unlawful deportation or transfer or unlawful confinement; and Taking of hostages.

Other Serious Violations of the Laws and Customs Applicable in Non-International Armed Conflict, within the established framework of international law, namely, Subparagraphs 8(2)(e)(i-vii) correspond to Article 8(2)(b) subparagraphs (i), (xxiv), (iii), (ix), (xvi), (xxii) and (xxvi) respectively. However, paragraph (e) adds, in paragraph (viii) Ordering the displacement of the civilian population for reasons related to the conflict, unless the security of the civilians involved or imperative military reasons so demand. Subparagraphs 8(2)(e)(ix-xii) correspond to Article 8(2)(b) subparagraphs (xi), (xii), (x) and (xiii) respectively. Subparagraphs (ii), (iv), (v), (vi), (vii), (viii), (xiv), (xv), (xvii), (xviii), (xix), (xx), (xxi), (xxiii), (xxiv) and (xxv) of Article 8(2)(b) were not incorporated into Article 8(2)(e). Article 8(2)(f) employs the limiting condition that appears in Article 1(2) of Protocol II.

Related with the crimes in Articles 6, 7, and 8, in fact, the impunity issue and the reparations issue are undoubtedly interrelated, certainly from the perspective of transitional justice in societies emerging from dark episodes of violence, persecution and repression. The work on both projects was only completed after some fifteen years of consultations and negotiations. The United Nations General Assembly adopted in 2005 by consensus the Basic Principles and Guidelines on the Right to a Remedy and Reparation for Victims of Gross Violations of International Human Rights Law and Serious Violations of International Humanitarian Law (hereinafter referred to as "the Principles and Guidelines") (reparation principles) and in the same year the then United Nations Commission on Human Rights (succeeded by the Human Rights Council in 2006) endorsed the Updated Set of principles for the protection and promotion of human rights through action to combat impunity (impunity principles) (E/CN.4/2005/102/Add.1).

The Principles and Guidelines have a preamble setting out their purpose and object. They are subsequently divided into the following thirteen sections containing a total of twenty seven articles:

$>$ Section I - Obligation to respect, ensure respect for and implement international human rights law and international humanitarian law;

$>$ Section II - Scope of the obligation;

> Section III - Gross violations of international human rights law and serious violations of international humanitarian law that constitute crimes under international law;

$>$ Section IV - Statutes of limitations;

$>$ Section V - Victims of gross violations of international human rights law and serious violations of international humanitarian law;

$>$ Section VI - Treatment of victims;

$>$ Section VII - Victims' right to remedies;

$>$ Section VIII - Access to justice;

$>$ Section IX - Reparation for harm suffered;

$>$ Section X - Access to relevant information concerning violations and reparation mechanisms;

$>$ Section XI - Non-discrimination;

$>$ Section XII - Non-derogation; and

$>$ Section XIII - Rights of others.

Broadly speaking, the first four sections, encompassing seven articles, affirm the obligations of States and legal implications in connection with gross violations of international human rights law and serious violations of international humanitarian law, notably the obligation to prevent violations, the obligation to investigate, prosecute and punish perpetrators, the obligation to provide effective access to justice to all persons alleging a violation, and the obligation to afford full reparation to victims (principles 1-4). The legal implications relate to and qualify universal jurisdiction, extradition, judicial assistance and cooperation as well as statutes of limitations (principles 5-7). 


\section{International Responsibility for Serious Human Rights Violations \\ 4.1 The State Responsibility in International Law}

In the aftermath of conflict, violence and suspicion often persist. Government institutions and the judiciary, which bear the main responsibility for the observation of human rights, are often severely weakened by the conflict or complicit in it. Yet, a general improvement in the human rights situation is essential for rehabilitation of war-torn societies. Many argue that healing the psychological scars caused by atrocities andreconciliation at the community level cannot take place if the truth about past crimes is not revealed and if human rights are not protected. To preserve political stability, human rights implementation must be managed effectively. Issues of mistrust and betrayal must be addressed, and the rule of law must be restored. In such an environment, the international community can often play an important supporting role in providing at least implicit guarantees that former opponents will not abandon the peace (Barbara F. Walter, 2002). Because all international norms are subject to cultural interpretation, external agents that assist in the restoration of human rights in post-conflict societies must be careful to find local terms with which to express human rights norms. While human rights are in theory universal, ideas about which basic needs should be guaranteed vary according to cultural, political, economic and religious circumstances. Consequently, policies to promote and protect human rights must be culturally adapted to avoid distrust and perceptions of intrusion into internal affairs.

The International Covenant on Civil and Political Rights (ICCPR) requires a state party "to respect and to ensure to all individuals within its territory and subject to its jurisdiction their international human rights." These obligations would seem relevant to any armed attack within a state's territory, where it clearly must both respect and ensure the human rights of its population (John C Dehn, 2012, p. 86).

The Article 2 aims at the practical implementation of human rights. In this it recalls article 2 of the International Covenant on Civil and Political Rights, which reads:

1. Each State Party to the present Covenant undertakes to respect and to ensure to all individuals within its territory and subject to its jurisdiction the rights recognized in the present Covenant, without distinction of any kind, such as race, colour, sex, language, religion, political or other opinion, national or social origin, property, birth or other status.

2. Where not already provided for by existing legislative or other measures, each State Party to the present Covenant undertakes to take the necessary steps, in accordance with its constitutional processes and with the provisions of the present Covenant, to adopt such laws or other measures as may be necessary to give effect to the rights recognized in the present Covenant.

3. Each State Party to the present Covenant undertakes:

(a) To ensure that any person whose rights or freedoms as herein recognized are violated shall have an effective remedy, notwithstanding that the violation has been committed by persons acting in an official capacity;

(b) To ensure that any person claiming such a remedy shall have his right thereto determined by competent judicial, administrative or legislative authorities, or by any other competent authority provided for by the legal system of the State, and to develop the possibilities of judicial remedy; and To ensure that the competent authorities shall enforce such remedies when granted.

Neglected Article 2 of the International Covenant on Civil and Political Rights 1966 by Republic of Indonesia, it to give the sense that mere talk of rights in national of regulations, and formal ratification of international agreements/instruments has no meaning, because rights are given meaning when they are implemented locally. If a state signs up to an international treaty on human rights, it must implement those rights and ensure adequate remedies for persons whose rights have been violated.

Human rights are universal and inalienable. All people everywhere in the world are entitled to them. The universality of human rights is encompassed in the words of Article 1 of the Universal Declaration of Human Rights: "All human beings are born free and equal in dignity and rights." In the Charter of the United Nations, human rights included as a principal aim of the UN, alongside international peace and security. However, in 1945 there was little agreement among people and governments about how human rights should be defined and the Charter does not define them either (Sunga, Lyal, S, 2002, p.47). The Universal Declaration of Human Rights is programmatic and general. Its provisions are not sufficiently specific or detailed to be implemented as law.

The Universal Declaration on Human Rights does express the international community's agreement on a common standard of achievement for all peoples and nations. As such, it provides the basis for the development of specific legal norms of international human rights law, norms that can claim a high level of consensus from all countries and peoples. The Declaration covers the principle of non-discrimination, freedom from slavery, torture, the right to be recognized as a legal person, the right to be treated equally, freedom from arbitrary arrest, detention or exile, fair trial, right to privacy, freedom of movement, right to seek asylum and to be free from persecution, right to a nationality, right to marry, own property, freedom of opinion and expression, freedom of association, right to take part in government, the rights to social security and to work. In Article 25, 
the Declaration provides for the right to a standard of living; in Article 26 the right to education; and in Article 27 the right to culture.

In the preamble to the Charter of the United Nations:

"We the peoples of the united nations determined: to save succeeding generations from the scourge of war, which twice in our lifetime has brought, untold sorrow to mankind, and to reaffirm faith in fundamental human rights, in the dignity and worth of the human person, in the equal rights of men and women and of nations large and small, and to establish conditions under which justice and respect for the obligations arising from treaties and other sources of international law can be maintained, and to promote social progress and better standards of life in larger freedom"

and; the "Purposes and Principles" of the United Nations, as set out in inter alia, Articles 1.2 and 2.12.4 respectively of the Charter of the United Nations. These include: respect for equal rights and selfdetermination of peoples (M. Bedjaoui, 1985, p.1074); sovereign equality of States; fulfillment in good faith of international obligations; settlement of international disputes by peaceful means (J-P, Cot \& A. Pellet, 1985, p.105); and prohibition of the threat or use of force against other States in any manner inconsistent with the purposes of the UN.

Article 2.1, provides, that setting out one of the purposes of the United Nations, provides in full: To develop friendly relations among nations based on respect for the principles of equal rights and selfdetermination of peoples, and to take other appropriate measures to strengthen universal peace"; while 2.1-2.4, provide as follows: The Organization and its Members, in pursuit of the Purposes stated in Article 1, shall act in accordance with the following Principles.

1. The Organization is based on the principle of the sovereign equality of all its Members;

2. All Members, in order to ensure to all of them the rights and benefits resulting from membership, shall fulfil in good faith the obligations assumed by them in accordance with the present Charter;

3. All Members shall settle their international disputes by peaceful means in such a manner that international peace and security, and justice, are not endangered; and

4. All Members shall refrain in their international relations from the threat or use of force against the territorial integrity or political independence of any state, or in any other manner inconsistent with the Purposes of the United Nations

The present-day normative system of human rights was embodied in international law by the two Intercontinental Covenants which entered into force in 1976. The system is subdivided into individual freedoms (civil and political rights) and economic, social and cultural rights. Thus, these fundamental rights, which are derived from the principle of human dignity, are to be viewed as the jus cogens of international law as formulated by the United Nations, and rules of jus cogens can be defined in general terms as being nonderogable rules of international 'public policy (M. Byers, 1997, p.211).

This follows especially from Resolution 2442 of the UN General Assembly of December 19,1968 (formulated with respect to articles 55 and 56 of the UN Charter), in which the obligation of all members of the international community towards the realization of the fundamental rights was expressly formulated. In the International Law Commission of the report, that there are three categories of elements that contrary to jus cogens, namely: The use or threat of force in contravention of the principle of the UN Charter; International crimes so characterized by international law; and Act or commissions whose suppression is required by international law.

Certain crimes affect the interests of the world community as a whole because they threaten the peace and security of humankind and because they shock the conscience of humanity. If both elements are present in a given crime, it can be concluded that it is part of jus cogens. The argument is less compelling, though still strong enough, if only one of these two elements is present. Implicit in the first, and sometimes in the second element, is the fact that the conduct in question is the product of state action or state-favoring policy. Thus, essentially, a jus cogens crime is characterized explicitly or implicitly by state policy or conduct, irrespective of whether it is manifested by commission or omission. The derivation of jus cogens crimes from state policy or action fundamentally distinguishes such crimes from other international crimes (M. Cherif Bassiouni, 1997, p.69)

The legal literature discloses that the following international crimes are jus cogens: aggression, genocide, crimes against humanity, war crimes, piracy, slavery and slave-related practices, and torture. Sufficient legal basis exists to reach the conclusion that all these crimes are part of jus cogens (U.N. Doc. S/RES/827, 1993 \& U.N. Doc.S/RES/955 (1994). This legal basis consists of the following:

1. International pronouncements, or what can be called international opinion juris, reflecting the recognition that these crimes are deemed part of general customary law;

2. Language in preambles or other provisions of treaties applicable to these crimes which indicates these crimes' higher status in international law;

3. The large number of states which have ratified treaties related to these crimes; and

4. The ad hoc international investigations and prosecutions of perpetrators of these crimes 
According to international law that state responsibility is a fundamental principle of international law derived from the doctrine of sovereignty and equality among nations, or state responsibility is a fundamental principle of international law arising out of nature the international legal system (Shaw, Malcom N,1991,p.481). In any legal system there must be liability for failure to observe obligation imposed by its rules. Municipal law distinguishes between civil and criminal liability based upon deliberate or negligent acts or omissions that constitute on offence under that law. In international law such liability is knows as responsibility. Responsibility arises for the breach of any obligation owed under international law (De Rover, Cess, 1987, p.57), so, It clearly, the law of state responsibility remains applicable to the violation by state of international-recognized human rights, because such an act constitutes a breach of international obligation (Cheng, B, 1999,p.93). A system (in the strictest sense of the word) can therefore only be understood as the sum of the universal norms which are implied in all subsystems, i.e. on which the validity of the systems is founded (Hans Köchler, 1980,p.2).

In some cases, the perceived need to protect human rights and maintain peace has led to humanitarian intervention. There is evidence that internationally we are moving towards the notion that governments have not only a negative duty to respect human rights, but also a positive duty to safeguard these rights, preserve life and protect people from having their rights violated by others (Don Hubert and Thomas G. Weiss et al., 2001, p.147), Many believe that states' duties to intervene should not be determined by proximity, but rather by the severity of the crisis.

In another side, responsibility to protect is a principle in international relations aimed at preventing genocide, war crimes, ethnic cleansing and crimes against humanity. This principle states that every country has a responsibility to protect people from the four types of crimes. Max Huber said that it is an indisputable principle that "responsibility is the necessary corollary of rights. All international rights entail international responsibility", (UNRIAA,Vol.1,1949,p.615), while according to the Italian-United States Conciliation Commission, no state may "escape the responsibility arising out of the exercise of an illicit action from the viewpoint of the general principles of international law (UNRIAA,VIXIV,1953,p.163).

The overview of the state responsibility among other the principle of international law and human rights is presented in the following figure.

Figure 2: The Responsibility to Protect as the Obligation of State

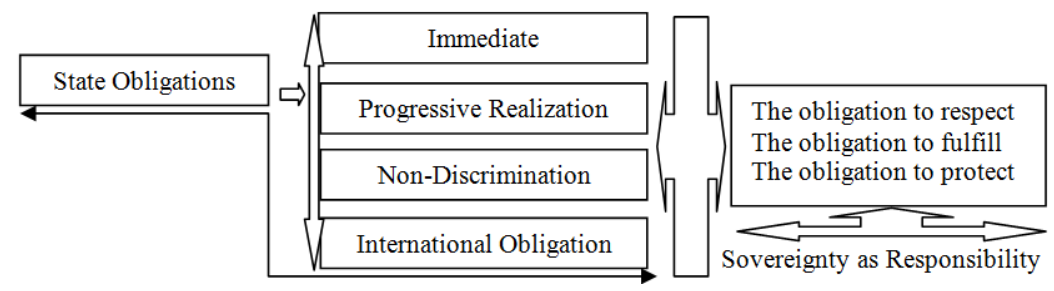

The obligation to respect means that states must refrain from interfering with or curtailing the enjoyment of human rights; the obligation to protect requires states to protect individuals and groups against human rights abuses; the obligation to fulfill means that states must take positive action to facilitate the enjoyment of basic human rights. As expounded by the Office of the UN High Commissioner for Human Rights.

Based on the "unity of normative knowledge of the theory of science", that the issue is not the "right to intervence" of any state, but the "Responsibility to Protect" of every state when it comes to people suffering from avoidable catastrophe-mass murder and rape, ethnic cleansing by forcible expulsion, deliberate starvation and exposure to disease" (Report of the UN), considering that "the principle that the state is responsible for act and commissions of organs of territorial government entities, such as municipalities, provinces and regions, has long been unequivocally recognized in international judicial decisions and the practice of state" (ILC,1974). For this, in Hugo Grotius's analysis (in Geoffrey Robertson QC, cited by the National Commission for Human Rights,2000,p.67) of the concept of state responsibility, state that the State and the ruling officials responsible for crimes committed by persons under his control, if they know and do not take precautions when they could and should do it.

Rolf Gössner (1978, p.226) state that, an intervention with the aim of reinstating human rights is rejected as violating international law. As a consistent system of norms, the binding force of the principles of human rights would be made possible only by abrogating the principle of sovereignty and vice versa.. This normative conflict is rooted in the Charter of the United Nations itself (Article 2, para.7 ["Nothing contained in the present Charter shall authorize the United Nations to intervene in matters which are essentially within the domestic jurisdiction of any state..."] and articles 1, 55, 56 ["the United Nations shall promote universal respect for, and observance of, human rights and fundamental freedoms for all without distinction...”]. 
In addition, the international community also has the responsibility to assist the countries in fulfilling the task. If, for various reasons, a state is unable or is unwilling to protect its people, then it becomes the responsibility of the international community to intervene in order to save people from genocide and also from various other crimes against humanity (Accountability and Rule of Law as one of the human rights principles).

The peremptory obligations are owed by all States (and other subjects of international law) to the international community of states as a whole. A significant step in this direction was taken by International Court of Justice in the Barcelona Traction case (P.32, Para.33) when it noted that:

"An essential distinction should be drawn between the obligations of a State towards the international community as a whole, and those arising vis-à-vis another State in the field of diplomatic protection. By their very nature the former are the concern of all States. In view of the importance of the rights involved, all States can be held to have a legal interest in their protection; they are obligations erga omnes......Such obligations derive, for example, in contemporary international law, from the outlawing of acts of aggression, and of genocide (IJC Reports, 1996, Para.52) as also from the principles and rules concerning the basic rights of the human person, including protection from slavery and racial discrimination" (ICJ Reports (1970), p. 3, at p. 32)

These erga omnes obligations have been defined as obligations of a State towards the international community as a whole, in the vindication of which all States have a legal interest. They are rules which accord a right to all States to make claims. As stated by Brownlie such rules are "opposable to, valid against, 'all the world', i.e. all other legal persons, irrespective of consent on the part of those thus affected."(Brownlie, 1990)

As affirmed in Article 1 of the internationally wrongful act of a state, that every internationally wrongful act of a State entails the international responsibility of that State, and Article 2, that there is an internationally wrongful act of a State when conduct consisting of an action or omission: (a) is attributable to the State under international law; and (b) constitutes a breach of an international obligation.

In sum, that the state is responsible for act and commissions of organs of territorial government entities has long been unequivocally recognized in international judicial decisions and the practice of states. The main elements in commander responsibility theory that applied in gross violation of human rights court were based on the decision of International Military Tribunal Nuremberg in Germany and International Military Tribunal Tokyo in Japan, the International Criminal Tribunal for Rwanda and International Criminal Tribunal for the Former Yugoslavia, that the action must showed similarity with elements such as the subordination relationship between commander and his member or superior inferior relationship; there is an acknowledge by commander or superior for his members were, subject to, or already did an actual or constructive violation of human rights; the commander or the superior with all of his power were failed to hindered, stopped or punished and transferred the violators to the authorities.

In terms of institutional implementation, the permanent Criminal Court would be only one, albeit the most important, among a number of possible means by which to enforce individual criminal responsibility for crimes under international law. For example, the creation of ad hoc international criminal tribunals, such as those of Nuremberg and Tokyo, or those created to deal with perpetrators of crimes committed in the former Yugoslavia or Rwanda, remains an important option open to the international community. Domestic courts retain the authority also to prosecute crimes under international law, although actual practice shows this has been done only very rarely (Bothe, Mc Alistair-Smith, Kurzidem, 1990)

\subsection{The Responsibility to Protect as a Duty of Care in International Law and Practice}

Paragraph 138 and 139 (2005, World Summit Outcome), aims at the practical implementation of responsibility to protect (UN. Resolution No.S/RES/1674, 16 April, 2006), which reads:

Paragraph 138: "Each individual State has the responsibility to protect its populations from genocide, war crimes, ethnic cleansing and crimes against humanity. This responsibility entails the prevention of such crimes, including their incitement, through appropriate and necessary means. We accept that responsibility and will act in accordance with it. The international community should, as appropriate, encourage and help States to exercise this responsibility and support the United Nations in establishing an early warning capability"

Paragraph 139: "The international community, through the United Nations, also has the responsibility to use appropriate diplomatic, humanitarian and other peaceful means, in accordance with Chapters VI and VIII of the Charter, to help protect populations from genocide, war crimes, ethnic cleansing and crimes against humanity. In this context, we are prepared to take collective action, in a timely and decisive manner, through the Security Council, in accordance with the Charter, including Chapter VII, on a case-by-case basis and in cooperation with relevant regional organizations as appropriate, should peaceful means be inadequate and national authorities manifestly fail to protect their populations from genocide, war crimes, ethnic cleansing and crimes against humanity. We stress the need for the General Assembly to continue consideration of the responsibility to protect populations from genocide, war crimes, ethnic cleansing and crimes against humanity and its implications, bearing in mind the principles of the Charter and international law. We also intend to commit ourselves, as necessary and appropriate, to helping States build capacity to protect their populations from genocide, war 
crimes, ethnic cleansing and crimes against humanity and to assisting those which are under stress before crises and conflicts break out"

Historically the principles of state responsibility and responsibility to protect have close links with human rights, where human rights which today have been set in international human rights law. Responsibility to protect concept focuses on the three pillars (UN Doc. A/Res/63/308, 2009), these are:

1. The Protection Responsibility of State. The responsibility of each individual state to protect its population from genocide, war crimes, ethnic cleansing, and crimes against humanity and their incitement;

2. The International Assistance and Capacity Building. The responsibility of the international community to undertake peaceful collective action to help states to exercise this responsibility; and

3. The Responsibility of the International Community. The responsibility of the international community to be prepared to take collective action in a timely and decisive manner through the United Nations Security Council.

Every Pillar in Responsibility to protect has values, and it essential to preventing crimes against humanity (Ban Ki Mon, Report, 2007). For these pillars was published in response by Secretary General Koffi Annan's challenges to General Assembly to reflect upon humanitarian intervention to protect civilians from 'wholesale slaughter' (Report, UN Doc.SG/SM/7136-GA/9596, 1999) Secretary general of UN concludes some practical recommendations (Lyal S Sunga, p.176-178) for all the states to responsible on internationally wrongful acts (Articles $1 \& 2$ ) through implementing responsibility to protect as a form the application of principle of the responsibility of state, considering for both of these principles is the duty or obligations in understand that sovereignty as the responsibility to respect, fulfill and protect the people as human being based on the principles of universal declaration of human rights.

The responsibility to protect embraces three specific responsibilities:

1. The responsibility to prevent: to address both the root causes and direct causes of internal conflict and other man-made crises putting populations at risk.

2. The responsibility to react: to respond to situations of compelling human need with appropriate measures, which may include coercive measures like sanctions and international prosecution, and in extreme cases military intervention.

3. The responsibility to rebuild: to provide, particularly after a military intervention, full assistance with recovery, reconstruction and reconciliation, addressing the causes of the harm the intervention was designed to halt or avert.

At first glance, it would seem that a state's "responsibility to protect" its population (Daniel Rice \& John Dehn, 2007, p.42-43) would prohibit a territorial state from allowing another state to attack individuals within its territory. After all, a state's responsibility to protect its population should apply equally to harm emanating from within or without its borders. A territorial state may therefore violate its human rights obligations by consenting to an attacking state's targeted killing operation.

\subsection{Human rights within the practices of state sovereignty}

Thinking of sovereignty as responsibility, in a way that is being increasingly recognized in state practice, has a three-fold significance. First, it implies that the state authorities are responsible for the functions of protecting the safety and lives of citizens and promotion of their welfare. Secondly, it suggests that the national political authorities are responsible to the citizens internally and to the international community through the UN. And thirdly, it means that the agents of state are responsible for their actions; that is to say, they are accountable for their acts of commission and omission (ISIS Report, G.A. Res. 60/1,120-122). A similar moral and legal right to infringe upon the sovereignty of a state is made when it fails in its obligation to protect its population from harm.

Sovereignty and human rights typically are seen as fundamentally opposed: the rights of states pitted against the rights of individuals; 1648 (the Peace of Westphalia) versus 1948 (the Universal Declaration of Human Rights). Sovereignty entitles states to non-interference in their internal affairs. There would seem to be few more purely internal matters than how a state treats its own nationals on its own territory. But that is precisely the focus of internationally recognized human rights. International human rights obligations thus are regularly seen as: assaulting (Mills, 1998, p.10; clapham,1999, p.533; Cardenas, 2002, p.57), challenging (Aceves,2002; Butenhoff,2003, p.215-216), besieging (Weiss \& Chopra,1995), undermining (Schwab \& Pollis,2000, p.214), busting (Lutz 1997, p.652), weakening (Jacobsen \& Lawson, 1999), chipping away at (Kearns, 2001, p.522), compromising (Krasner, 1999, p.125), contradicting (Forsythe, 1989, p.6), breaking down (Bettati,1996, p.92), breaching (Lyons \& Mayall,2003, p.9), perforating (van Hoof , 1998, p.51), or eroding (Ayoob,2002, p.93; Henkin,1999, p.3-4; Lapidoth,1995). State sovereignty-which is presented as giving way (Aceves,2002, p.265), even surrendering (Lauterpacht,1968 [1950], p.304-311), to higher human rights norms that "provide legal and moral grounds for disregarding the sovereign rights of States." (Shen,2000, 
p.435) "Human rights have revolutionized the international system and international law." (Henkin,1995, p.4344). According to Steinberger (2000, p.512) "A sovereign state "is not subject, within its territorial jurisdiction, to the governmental, executive, legislative, or judicial jurisdiction of a foreign State or to foreign law other than public international law", and (p.518) "Sovereignty is a legal status within but not above public international law. As a juridical status protected by international law, it is embedded within the normative order of this law" Jennings \& Watts (1992, p.122) "International law replicates this ordinary understanding."Sovereignty is supreme authority."

Wheaton (1866, p.31) "Sovereignty is the supreme power by which any State is governed"

Vattel (1916 [1758]: Bk. II, Ch. IV) "The sovereign is the person to whom the Nation has confided the supreme power and the duty of governing."

While in the Black's Law Dictionary, $7^{\text {th }}$ edition, (1999) "Sovereignty: 1) Supreme dominion, authority, or rule. 2) The supreme political authority of an independent state. Supremacy, the right to demand obedience"

"Current legal theory holds that countries are totally able to determine their own internal policies." (Brown \& Alexander,1994). This is nonsense. Sovereignty is the right, not the ability, to determine one's policies. Like any right it may or may not be effectively enjoyed, infringed, violated, or ignored. "Sovereignty has become steadily less absolute. Even for a so-called superpower internationalism is inescapable." (Howe 1995, p.129) Unilateralism and internationalism, however, have nothing to do with sovereignty (supreme authority in one's own territory). They concern the costs and benefits of unilateral or collective action. "No sovereign state, and not all state sovereignties together, seem to be sovereign enough to solve the problems of our human society at the end of the twentieth century" (Henkin,1999, p.6). Sovereign authority, however, is no guarantee of the capability to solve any particular problem. These sovereigns recognized each other, not abstract territorial entities. And the rights of sovereigns are determined by the practices of the society of sovereign states, not by theoretical or conceptual logic.

Oscar Schachter (1991, p.50) has developed one of the more comprehensive accounts of the various possible meanings of the term general principles. Five types of principles invoked in international law:

1. Principles of municipal law that are recognized by civilized nations; (id, p.50-53)

2. Principles that are derived from the unique character of the international community, such as the principles of territorial integrity and sovereign equality of states; (id, p.53)

3. Principles that are "intrinsic to the idea of law and basic to all legal systems," which are implicit in or generally accepted by all legal systems and are necessary based on the logic of the law; (id, 53-54)

4. Universalist principles that are "valid through all kinds of human societies" and that echo the idea of natural law, such as the principles of human rights; (id, p.54-55), and

5. Principles of justice that are premised on the rational and social nature of human beings and that include principles of natural justice outlined in human rights instruments and the concept of equity (id).

The Rome Statute certainly authorizes the ICC to apply general principles. Article 21(1) of the Statute on "Applicable Law" establishes the following hierarchy of sources: first, the Statute, Elements of Crimes, and Rules of Procedure and Evidence; second, treaties, principles, and rules of international law; and failing that, general principles of law derived from laws of domestic legal systems, including those of the state that would normally have jurisdiction, as long as they are consistent with the Statute and with international law.

According to Judge Stephen, a general principle of law rested on an inquiry into the rationale behind the existence of the actual rules of the legal systems in question. The common law's exception in the case of murder was based on an understanding that the law may never endorse the accused's choosing his life over the taking of an innocent one. It would thus do no violence to the common law to accept duress as a defense in situations where this choice was wholly absent (Prosecutor v Erdemovi's case No. IT-96-22-A, p.64-66). General principles of international law for a solution (Prosecutor v Anto Furund zija' case No. IT-95-17/1-T, 1998), considering general principle in the concept of human dignity, which was fundamental to international humanitarian and human rights law and permeated the corpus of international law as a whole (Neha Jain, 2016, p.124)

Furthermore, the Universal Declaration on Human Rights (1948), the International Human Rights Covenants (1966), and several single-issue treaties and declarations establish an impressive body of international legal obligations. These instruments regularly use the language of universal rights: "No one shall be," "Everyone has the right" but universal human rights have been embedded in a statist system of national implementation. (Donnelly, Jack, 2003). The international human rights obligations of states are solely to their own nationals (and others under their territorial jurisdiction). States have neither a right nor a responsibility to implement or enforce the human rights of foreigners on foreign territory. And international supervision of national human rights practices is extremely restricted.

The effort to prosecuted and to put on trial for head of state, military leaders, the chief of police officers and other civilian leaders, for the gross violation of human rights in Aceh is a very serious legal problem which 
can't be pull to be aside and is the main concern in this research. The most important thing that Jus cogens crimes is not only a domestic concern of a nation but it already became an international concern, in order to cut loose the chain impunity practice. The question of human rights is no longer the preserve of the domestic jurisdiction of states, but is now recognized as being governed by internal law and by international law, against which special internal law cannot be invoked (Hestor Gross Espiell, 2000, p.349) hence, state which violates the right will be sentenced as a state with gross violation of human rights.

The Resolution 308 on the Responsibility to Protect, provide that each individual states has the responsibility to protect its populations from genocide, war crimes, ethnic cleansing and crimes against humanity, including through preventive measures. At the same time, the Security Council echoed the concept in a number of important resolutions, as for example Resolution 1325 which 'emphasizes the responsibility of all States to put an end to impunity, and war crimes including those relating to sexual and other violence against women and girls (Paragraph 11, UN Security Council Res.1325, 2000) Security Council Resolutions 1674 and 1894 on the Protection of Civilians in Armed Conflict also reaffirmed the Outcome Document and the Council's strong opposition to impunity for 'serious violations of human rights and humanitarian law (Paragraph 4, UNSC Res.1674, 2006).

In addition to international human rights norms, states, largely irrespective of their will, are bound by the norms of customary international law, obligations erga omnes, and jus cogens. So long as international obligations do not subordinate states to a higher authority-and they clearly do not in the case of the global human rights regime-they are completely compatible with full sovereignty. Supremacy means that one is subject to no higher authority, not that one's authority is absolute and unlimited.

\section{Jus cogens crimes in Aceh is the product of state action or by state policy}

In the perspective of human rights law, that the state can be seen as violators of human rights. The country in question is the whole institution and the state that is under the executive, legislative and judicial branches. A violation can be in direct or in the form of action or policy decisions. Even so, they remained subject is based on individual officials and/or the officer who made or authorized. The party responsible for these violations in the hierarchy can be traced from the actor who issued the policy to the field actors implementing the policy.

A state's political policy or terms of decision making in a country is the policy or decisions taken collectively and the decision is binding on the whole community. Policies that have been taken or decided by the state, especially in the field of defense and security could potentially or even cause casualties or gross violations of human rights. The policy caused casualties that can't be justified or have no reason for that action, the consequences will gather national and international opinion (the international community) that acts or measures taken by a state or authority in a country is an international crime. Genocide and crimes against humanity constituted international crimes that rise to the level of jus cogens constitute obligation erga omnes which are inderogable. State which violates the right will be sentenced as a state with gross violation of human rights.

If the violation is not equal to the failure to respect and ensure but amounts to a consistent policy, it ceases when this policy is abandoned. In political reality, this means legislative, judicial and administrative action relating to fields or individual and group cases where violations have taken place, but also a profound and general upheaval. As a rule, not only the government is removed from office but sweeping constitutional changes take place. International identity of the state is preserved, but in the eyes of the population this could be a mere fiction. For them, there is a new state associated with the new regime. This feeling is shared by the members of the new government and the new elite. Mostly composed of former dissidents and victims of human rights violations, they do not feel responsible for the deeds and misdeeds of the "old" state. Legal problems have to be considered against this political and socio-psychological background.

Furthermore, the fact of Aceh, the most people don't know what happen with the rights of Acehnese during 30 years in the circle of Indonesia government's policy, here, the author need to explain it to the world, or to make a brief chronological review on one of the long-lasting conflicts in Southeast Asia.

The Aceh province is located at the Northern end of the island of Sumatra, which had established for hundred years as an internationally recognized state before the European conquerors arrived. On 26 March 1873 the Kingdom of the Netherlands declared war on the Sultanate of Aceh. It was the most bloodies war in the Dutch colonial history with estimated over 100.000 deaths. One of the war atrocities was the tragedy of Kuta Réh in remote highland area Gayo in Central of Aceh on 14 June 1904, where 130 bodies of 561 villagers killed were identified as children (Paul Bijl, 2015:103-106). But, the Dutch government has not even made an apology for this well documented massacre and other human rights crimes for 70 years of its invasion of Aceh between 1873 until 1942 (Ariffadhillah, 2016:1). Aceh was forcefully incorporated through military conflict first by the Netherlands into the Dutch East Indies, and then by Indonesia.

During the Second World War, the Japanese troops occupied the Acheh territory. An example for atrocities was the execution of a religious leader, Teungku Abdul Djalil Tjot Plieng and over 120 of his 
followers, in Bayu, North Acheh in November 1942, and After the Second World War the Dutch troops had never returned to Acheh anymore, but the Dutch government transferred illegally the sovereignty of Acheh to a newly fabricated state called Indonesia, on 27 December 1949. Thus, the first violation of the UN decolonization principles took place, as far as the vast Malay Archipelago was concerned. Whereas all Western colonial empires were decolonized by returning each colonial territory to its indigenous peoples and became independent, the Dutch East Indies has never been returned to the respective indigenous peoples from whom the Dutch had confiscated the territories. The Dutch gave their entire colonial empire of the Dutch Indies - not to the respective rightful owners of the separate territories, as required by the decolonization rule and principles, but to the new entity, the Jakarta based "Republic of Indonesia"

After strenuously resisting Dutch colonial domination, the region was incorporated into the Dutch East Indies and it subsequently became part of Indonesia when the country became independent in 1949. After alternating waves of conflict between local forces or Aceh Free Movement (Schulze, Kristen E, 2004, p. 30) demanding independence and the central government, a peace agreement was signed in 2005, resulting in the establishment of a regional government. In addition to the numerous human rights abuses perpetrated during the conflict, which are still to be addressed, Aceh faces issues related to land exploitation and internal displacement caused by the Indonesian government's transmigration polices. Additionally, Aceh was hit by a deadly Tsunami in 2004 and, despite positive a post-tsunami reconstruction effort, economic life in Aceh has not yet completely recovered (UNPO, Report to CESCR-EC.12/IDN/1, 2014, p. 4).

In 1952 the UN General Assembly stated in Resolution 637A-VII, that the right of peoples and nations for self determination is a prerequisite to the full enjoyment of all fundamental human rights. In the case of Acheh, given the tragic fact that the once independent Achehnese have been subjected to centuries of oppression by Dutch, Japanese and Indonesian colonialists, it is not difficult to understand why the Achehnese firmly believe that independence is the only way forward to resolve the conflict. Therefore it is the responsibility of the international community, including the EU, which actively involved in the Helsinki MoU negotiation, to support and uphold the rights of the Achehnese (Article 1.1, states that all peoples have the right of self-determination. By virtue of that right they freely determine their political status and freely pursue their economic, social and cultural development)

The Indonesian report submitted to the Committee regards the right of self-determination as ultimately implemented by the Proclamation of Independence of 1945 with "the consensus of all Indonesian people" (EC.12/IDN/1, January 2012). Historically, however, consensus was not what led to the incorporation of West Papua, South Moluccas, and Aceh into the Indonesian Republic. Indeed, all these three regions declared their independence and developed movements opposing the Indonesian central authority and unitary ideology.

On 4 December 1976, Dr. Hasan Muhammad di Tiro (Wali Nanggroe), a Doctor of Law (international law), graduated of Columbia University, USA, also as a UN member. As a Chairman of the Aceh Free Movement, he re-declared the independence of Aceh based undoubtedly on UN Resolutions such as, the UN Resolution 1514XV, UN Resolution 2621XXV, UN Resolution 2711XXV, UN Resolution 3314XXIX, as well as all relevant Articles of The Charter of the United Nations, The Universal Declaration of the Rights of the Peoples, the Universal Declaration of Human Rights, The International Covenant on Economic, Social and Cultural Rights, The International Covenant on Civil and Political Rights.

In addition, through the statements of Dr.Tengku Hasan Muhammad di Tiro (1968:56) related the second war (5-23 April, 1973:11; Dec'1873-Dec'1911:35; and Dec'1911-March 1942:51), and Jean Pictet (1985:79), seem that there have relationship between the conduct of the Government against the civilian persons including members of armed force/combatants who have laid down their weapons in time of war, and showed that the effect of non international armed conflict resulted million persons deaths, or World War I and II killed 50 million persons including about as many civilians as combatants caused by Government's policies as the final solution, such as the Nazi Government's policy against German Jews, Sinti and Roma populations (Lyal S. Sunga, 2008, p.1), including the Indonesia Government's policy against West Papua, South Moluccas, and Aceh populations.

During non-international armed conflict or internal conflict in Aceh (30 years), resulted 7.727 gross violations of human rights of cases since Indonesia Government have to applied the military operation through the dark-pattern or state violence (The National Commission for Human Rights of the report, 2000, p.2), such as, Murder; Enforced disappearance of persons; Extermination; Torture and other cruel; Persecution against any identifiable group or collective; Imprisonment or other severe deprivation of physical liberty in violation of fundamental rules of international law; Other inhumane acts of a similar character intentionally causing great suffering, or serious injury to body or to mental or physical health; arbitrary arrest and detention; rape and sexual assault; destruction of property; including genocide of crime.

While the erga omnes nature just mentioned appertains to the area of international enforcement (lato sensu), the other major feature of the principle proscribing international crime relates to the hierarchy of rules in the international normative order. Because of the importance of the values it protects, this principle has evolved 
into a peremptory norm or jus cogens, that is, a norm that enjoys a higher rank in the international hierarchy than treaty law and even "ordinary" customary rules. The most conspicuous consequence of this higher rank is that the principle at issue cannot be derogated from by States through international treaties or local or special customs or even general customary rules not endowed with the same normative force.

Torture in times of armed conflict is specifically prohibited by international treaty law, in particular by the Geneva Conventions of 1949 and the two Additional Protocols of 1977, namely, in Articles 3,12 and 50 of Geneva Convention I for the Amelioration of the Condition of Wounded and Sick in Armed Forces in the Field, 12 Augustus 1949; Articles 12 and 51 of Geneva Convention II for the Amelioration of the Condition of Wounded, Sick and Shipwrecked Members of the Armed Forces at Sea, 12 Augustus 1949; Articles 13,14 and 130 of Geneva Convention III Relative to the Treatment of Prisoners of War, 12 Augustus 1949; Articles 27, 32 and 147 of Geneva Convention IV Relative to the Protection of Civilian Persons in Time of War, 12 Augustus 1949, hereafter "Geneva Convention IV; including in Article 75 of Geneva Protocol Additional to the Geneva Conventions of 12 Augustus 1949, and Relating to the Victims of International Armed Conflicts (Protocol I), 8 June 1977, hereafter "Additional Protocol I"; and Article 4 of Geneva Protocol Additional to the Geneva Conventions of 12 Augustus 1949, and Relating to the Victims of Non-International Armed Conflicts (Protocol II), 8 June 1977

In spite of seeking peaceful conflict resolution, the government of the Republic of Indonesia under dictator President Soeharto launched massive military operations against members and followers of the pro independence movement. The military operations caused tens of thousands casualties and uncountable serious human rights violations. Since May 1989, the military operations were still continued, even more intensive than before in the post Suharto (Miller, Michelle Ann, 2008 \& John H. Mc. Glynn, 2005) era resulting many massacres (Ariffadhillah, 2016, p.2) among others:

1. Massacre at KNPI Building, Lhôk Seumawè, North Aceh.

On 9 January 1999, The Indonesian troops persecuted the detainees in the youth organization building, caused 5 death 44 seriously injured;

2. Massacre of Arakundo River, Idi Tjut, East Aceh.

On 4 February 1999, caused dozens death and hundreds seriously injured;

3. Massacre of Simpang KKA, Kruëng Geukueh, North Aceh.

On 3 May 1999, the Indonesian troops shot on a gathering, caused 46 death (six of them were children), 156 seriously injured from gunshot wounds, 10 missing;

4. Massacre of Beutông Ateuëh, West Aceh.

On 23 July 1999, the Indonesian Army executed a religious leader named Teungku Bantaqiah and more than seventy of his students in front of his boarding school;

5. Massacre of Bumi Flora, Idi, East Aceh. On 9 August 2001, the Indonesian army dressed in camouflage uniforms entered one of the housing areas of PT Bumi Flora, a rubber and palm oil plantation in East Aceh, and shot thirty men and a two year old child to death. Seven others were wounded; and

6. Massacre of Jambô Keupok, South Aceh.

On 17 May 2003, dozens of Indonesian soldiers the Special Army Forces and Raider units arrived in three trucks at the village of Jambo Keupok in South Aceh. After rounding up everyone at the village and separating the men from the women and children, soldiers shot and killed four villagers. Twelve men, who were also beaten, had their hands tied and were taken to a house nearby, locked up and the house set alight. The women and children, who were locked up in a school building, were able to leave once the military had left.

Indonesia Government has admitted that in Aceh has occurred the gross violation of human rights as described in the preamble of Decree No.88 of 1999, 30 July 1999 on the Independent Commission Investigation to the violence in Aceh. For the same thing can be found in another document (PD/27/2000, the last 2013) through the National Commission for Human Rights. Other sources also described by Adwani, a professor of law at Syiah Kuala University, Aceh, Indonesia, provides that persons that involved in an armed conflict are protected by law which regulated in Article 13 of the Geneva Convention 1949. There are some persons who receive protection such as combatants, militia and levee en masee, and civilians as a matter of law, however, the protection itself has not been fully implemented. In principle, persons who involve in an armed conflict must protect the combatants who took direct participation when the combatants are wounded and hostile. However, the protections are not implemented accordingly since they often receive violence attacks. Furthermore, civilians often become victim of attack that classified as inhuman treatment, such as Iraq, Libya, Palestine, Including Indonesia, namely Aceh, West Papua (Adwani, 2012,p.1-2), and South Moluccas (Scott Cunliffe \& et all, 2009)

Although all the cases has discussed by the Chairman of Presidium of Aceh Sumatra National Liberation Front in European Parliament Conference at European Parliament, Brussels on June 2016, attended by the Unrepresented Nations and Peoples Organization, the Taiwan Foundation for Democracy, the Haëlla Foundation, and etc. At the same time, the UNPO has argues the Republic of Indonesia to consider his 
recommendations, or implementing some articles of the Committee of Economic, Social and Cultural Rights, such as Articles 1.para.1 and 2 (Right of self-determination); Art.2.para.2, (Non-Discrimination); Art.6, para.1 \& Art.7 (Right to Work); Art.8 para.1 (Right to Strike); Art.11, para.1 (Right to adequate standard of living); Art.12 (Right to health); Art.13 (Right to Education); Art.15 (Cultural Rights).

In 2002, through the mapping of transnational justice initiative of civil society in Indonesia, (Hilmar Farid \& Rikardo Simarmatra, 2004), the National Commission for Human Rights recommended those actors to be prosecuted by the responsibility of commanders (Article 28 subparagraph (a) and individual criminal responsibility (Article 25 paragraph 1, 2 and 3 subparagraph (a), (b), (c), (d), and (f), including the crime of genocide, it provide that in respect of the crime of genocide, directly and publicly incites others to commit genocide, as affirmed in subparagraph (e) of the Rome Statute, as the responsibility of state. In reality that all of those defendants who were charged for gross violation of human rights by commander responsibility and individual criminal responsibility principles as state violence were awarded with a free sentence and those sentences were all binding by law. The argument for that sentences was because the defendants were not in superior position for those actors who done the gross violation of human rights, defendants did not have any hierarchy line of command and did not have any effective control for those who committed gross violation of human rights. Seem that the Indonesia Government unable or unwillingness to solving that problems who's happened for long years ago. Considering all the process is not matching with the international human rights standards in International Criminal Court procedures, therefore, the mechanism to resolve it could be diverted to International Criminal Court based on the Article 20 paragraph 2 and 3, Article 13 subparagraph (b) of the Rome Statute of the International Criminal Court, including Articles 41 and 42 of the International Covenant on Civil and Political Rights, all these cases will taken by International Criminal Court. Human rights are implemented via institutions of justice: the police, prosecutors and judiciary. If these are not functioning according to the rule of law, human rights cannot be realized, and if the ICC lends the impression of being driven by politics rather than justice it will lose legitimacy and eventually become ineffective.

\section{CONCLUSION}

The Indonesia Government as the actor of Jus Cogens Crimes, such as crime of genocide and crimes against humanity that occurred in Aceh. Therefore for those crimes, the Government has the legal obligations as a form of accountability of state, inter alia the duty to prosecute or extradite, the non-applicability of statues of limitations, the non-applicability of any immunities up to and including heads of state or President of the Republic of Indonesia, and the defense of “obedience to superior orders" If Indonesia can't apply or handle it, accordingly Article 12 paragraph 3 on preconditions to the exercise of jurisdiction of the Rome Statute, that's case can take by international criminal court, even though Indonesia as a state which is not a party to this statute (non-party, non-signatory). Its means that jus cogens crimes is not only a domestic concern of a nation but it already became an international concern, in order to cut loose the chain impunity practice. It is generally assumed that human rights are embodied in international law and that, according to the process of their adoption, human rights are founded on the mechanisms of international law.

Finally, this research hopes to contribute to seeking a solution for developing the overall national legal system through the harmonization of national legal regulations with respect to international human rights instrument in efforts of settlement of the gross violation of human rights during non international armed conflict in Aceh. In process of justice, considering, one of the urgency to enacted the Law No 26 of 2000 concerning Human Right Court as the basic to anticipate the formation of International Criminal, such as, the International Criminal Court Tribunal for the Rwanda and International Criminal Tribunal for Yugoslavia by the United Nation Security Council, legal protection for those who become victims of gross violation of human rights, to cut loose the impunity practices in gross violation of human rights, to answered any problems occurred by gross violation of human rights toward humanity will it become a recurrent issues or burning issues facing by Indonesian Government and to fulfill the legal loophole in human rights regulation in Indonesia.

\section{REFERENCES}

\section{Journal Papers}

[1]. Ayoob, Mohammed. Humanitarian Intervention and State Sovereignty. International Journal of Human Rights 6 (1):81-102, 2002.

[2]. Adwani, Perlindungan Terhadap Orang-Orang Dalam Daerah Konflik Bersenjata Menurut Hukum Humaniter Internasional, Jurnal Dinamika Hukum, Vol.12 No.1, 2012

[3]. Brown, Robert, and Michael Alexander, Sovereignty in the Modern Age. Canada United States Law Journal 20:273-296, 1994

[4]. E.G. Orentlicher, D.F, Setting Accounts: The Duty to Prosecute Human Rights Violations of a Prior Regime, 100 Yale Law Journal, (pp.2361,2568), 1991. 
[5]. Bettati, Mario, The International Community and Limitations of Sovereignty. Diogenes 44 (4):91-109, 1996

[6]. Daniel Rice \& John Dehn, Armed Humanitarian Intervention: A Primer for Military Professionals, 87 Mil. Rev. 38, 42-43 (2007)

[7]. Hans Köchler, The Principles of International Law and Human Rights: The Compatibility of Two Normative Systems. Studies in International Relations, Vol. V. Vienna: International Progress Organization, 1991

[8]. Howe, Geoffrey. Sovereignty Democracy and Human Rights. Political Quarterly 43 (4):79-95, 1995.

[9]. Henkin, Louis, Human Rights and State 'Sovereignty'. Georgia Journal of International and Comparative Law 25 (1-2):31-45, 1995

[10]. Hans Kelsen, Das Problem der Souvenerätät und die Theorie des Völkrrechts. Tübingen, 1928

[11]. John C Dehn, Targeted Killing, Human Rights and Ungoverned Spaces: Considering Territorial State Human Rights Obligations, Harvard International Law Journal, Vol. 54, (An article from the symposium, "State Ethics: Controlling the Behavior of Governments and Their Partners"), Copyright by the President and Fellows of Harvard College, 2012

[12]. Jacobsen, Michael, and Stephanie Lawson. Between Globalization and Localization: A Case Study of Human Rights Versus State Sovereignty. Global Governance 5 (2):203-219, 1999

[13]. Kearns, Temple Fett, Breaking the Shackles of the Past: The Role and Future of State Sovereignty in Today's International Human Rights Arena. Nova Law Review 25:502-524, 2001

[14]. Lutz, Ellen L, Strengthening Core Values in the America: Regional Commitment to Democracy and the Protection of Human Rights. Houston Journal of International Law 19:643-657, 1997.

[15]. M. Byers, Conseptualizing the Relationship between Jus Cogens and Erga Omnes Rules, Vol. 66, Nordic Journal of Internatioal Law, 1997.

[16]. Miller, Michelle Ann, Rebellion and Reform in Indonesia. Jakarta's Security and Autonomy Policies in Aceh, London: Routledge, 2008, ISBN 978-0-415-45467-4

[17]. M. Bedjaoui, Commentary to Article 73 of the Charter, in J-P. Cot and A. Pellet, La Charte des Nations Unies, 1985

[18]. M. Cherif Bassiouni.,International Crimes: Jus Cogens And Obligation Erga Omnes, Vol.59 No. 4, 1997

[19]. Neha Jain, Judicial Law making and General Principles of Law in International Criminal Law, Harvard International Law Journal, Vol. 57, No.1 Winter, 2016

[20]. Rolf Gossner, "Der Menschenrechtsschutz im Rahmen der Vereinten Nationen: Internationaler Menschenrechtsschutz und Staaliche Soveranitat, in Demokratie und Rech, Vol.6,1978

[21]. Shen, Jianming, National Sovereignty and Human Rights in a Positive Law Context. Brooklyn Journal of International Law 26:417-446, 2000

[22]. Schulze, Kirsten E, The Free Aceh Movement: Anatomy of a Separatist Organization. Washington: EastWest Center Washington, 2004, ISBN 1-932728-03-1

\section{Chapters in Books}

[23]. Yearbook of the ILC, Part 2 at 75, UN Doc. A/CN.4/Ser.A/1976, Add.1, Pt.1

Books

[24]. Antonio Cassese (1990), Human Rights in a Changing World (Philadelphia: Temple University Press.

[25]. Aceves, William J (2002), Relative Normativity: Challenging the Sovereignty Norm through Human Rights Litigation. Hasting International and Comparative Law Review 25:261

[26]. Alasdair McIntyre (1984), After Virtue, 2nd Edition

[27]. Butenhoff, Linda (2003), Localizing Human Rights in an Era of Globalization: The Case of Hong Kong in Constructing Human Rights in the Age of Globalization, edited by M. Monshapoori, N. Engel hart, A.J. Nathan and K. Philip. Armonk: M. E .Sharpe.

[28]. Bayefsky F. Anne (2000), The UN Human Rights Treaty System in the 21st Century. The Hague: Kluwer Law International.

[29]. Barbara F. Walter (2002), Committing to Peace: the Successful Settlement of Civil Wars. Princeton, N.J., Princeton University Press Brownlie, Ian (2003), Principles of Public International Law, $6^{\text {th }}$ ed, Oxford: Oxford University Press.

[30]. Bothe, Mc Alistair-Smith, Kurzidem, (1990), National Implementation of International Humanitarian Law.

[31]. Clapham, Cristopher (1999), Sovereignty and the third World State, Political Studies 47 (3):522-538

[32]. Cheng Bin, (2000), The General Principle of law Applied by International Court and Trubunals, Cambridge Institue Limited.

[33]. Cardenas, Sonia (2002), National Human Rights Commissions in Asia: In Sovereignty under Challenge, edited by J.D. Montgomery and N. Glazer. New Brunswick: Transaction Publishers

[34]. Ch. Bassiouni (1992), Crimes against Humanity in International Criminal Law. 
[35]. Don Hubert and Thomas G. Weiss ett al (2001), The Responsibility to Protect: Supplementary Volume to the Report of the International Commission on Intervention and State Sovereignty (Canada: International Development Research Center)

[36]. Donnelly, Jack (2003), Universal Human Rights in Theory and Practice, $2^{\text {nd }}$ ed. Ithaca: Cornell University Press.

[37]. De Rover, Cess, (1998), To Serve and To Protect Human Rights and Humanitarian Law for Police and Security Forces, Geneva, ICRC.

[38]. Dormenyal, A (1991), Procédures onusiennes de mise oeuvre des droits de l'homme: limites ou défauts? Paris: Presses Universitaires de France

[39]. Forsythe, David .P (1989), Human Rights and World Politics, $2^{\text {nd }}$ ed, Lincoln, University Nebraska Press

[40]. Hilmar Farid and Rikardo Simarmatra (2004), The Struggle for Truth and Justice: A Survey of Transitional Justice Initiatives throughout Indonesia, ICTJ, New York: ICTJ.

[41]. Hestor Gross Espiell, (2000), Humanitarian Law and Human Rights, in Januzy Symonides (editor), Human Rights: Concept and Standards, Paris: UNESCO.

[42]. Hasan Muhammad di Tiro, Teungku, (1968), Atjèh Bak Mata Donja, Institute Atjeh di Amerika, New York.

[43]. ----------------- (1984) The Price of Freedom: The Unfinished Diary of Tengku Hasan Di Tiro, Published by National Liberation Front of Acheh Sumatra.

[44]. Jennings, Robert and Arthur Watts (1992), Oppenheim's International Law, $9^{\text {th }}$ ed. Harlow: Longmans.

[45]. John H. Mc Glynn, (2005), Indonesia in the Soeharto Years: Issues, Incidents and Images, Jakarta, Lontar Foundation.

[46]. Krasner, Stephen D (1999), Sovereignty: Organized Hypocrisy. Princeton: Princeton University Press

[47]. Lauterpacht, H 1968 (1950), International Law and Human Rights, n.p: Archon Books

[48]. Lyons, Gene M, and James Mayall (2003), Stating the Problems of Group Rights. In International Human Rights in the $21^{\text {st }}$ Century: Protecting the Rights of Groups, edited by G.M. Lyons and J. Maryall. Lanham: Rowman \& Littlefield.

[49]. Mills, Kurt (1998), Human Rights in an Emerging Global Order: A New Sovereignty, New York: St. Martin's Press

[50]. Manan, B, (1994), Dasar-Dasar Konstitusional Peraturan Perundang-undangan Nasional (Fundamental of Constitutional Laws and Regulation), Padang, Fakultas Hukum Universitas Andalas

[51]. Oscar Schachter (1991), International Law in Theory and Pravtice.

[52]. Picted, Jean (1985), the Nature of Humanitarian Law, Martinus Nijhoff Publishers, Geneva.

[53]. Sunga, Lyal, S (2008), What Makes Democracy Good?, Chapter 6 in Gudmundur Alfredsson et al (eds), International Human Rights Monitoring Mechanisms Essays in Honour of Jakob Th. Möller, 2nd Revised Edition, Martinus Nijhoff, 2009.

[54]. ---------------, (1992), Individual Responsibility in International Law for Serious Human Rights Violations

[55]. --------------, (2008), The Human Rights Council, An Institutional Approach to the Responsibility to Protect, Edited by Gentian Zyberi \& Kevin T. Mason, Cambridge University Press.

[56]. Schwab, Peter, and Adamantia Pollis (2000), Globalization's Impact on Human Rights. In Human Rights: New Perspective, New Realities, eduted by A. Pollis and P. Schwab. Boulder: Lynne Reinner Publishers

[57]. Schmid, A.P (1989), Research on Gross Human Rights Violations, 2 ed., Leiden: Center for the Study of Social Conflicts, University of Leiden.

[58]. Scott Cunliffe, et all (2009), Negotiating Peace in Indonesia: Prospect for Building Peace and Upholding Justice in Maluku and Aceh, New York ICTJ

[59]. Steinberger, Helmut (2000), Sovereignty. In Encyclopedia of Public International Law, edited by R. Bernhardt, Amsterdam: North-Holland Elsevier.

[60]. Shaw, Malcom N, (1991), International Law, Third Edition, Grotius Publication Limited, Cambridge

[61]. Vattel, Emerich 1916 (1758), the Law of Nations or the Principles of Natural Law Applied to the Conduct of the Affairs of Nations and of Sovereigns. Washington, D.C: The Carnegie Institution of Washington.

[62]. Van Hoof, Fried (1998), International Human Rights Obligations for Companies and Domestic Court: An Unlikely Combination? In The Role of the Nation-State in the $21^{\text {st }}$ Century: Human Rights, International Organizations and Foreign Policy. Essay in Honour of Peter Baebr, edited by M. Castermans-Holleman, F.van Hoof and J.Smith. The Hague: Kluwer Law International.

[63]. Wheaton, Henry (1866), Elements of International Law, $8^{\text {th }}$ ed, Boston: Little, Brown, and Company

[64]. Weis, Thomas G, and Jarat Chopra (1995), Sovereignty Under Siege: From Intervention to Humanitarian Space in Beyond Westphalia?: State Sovereignty and International Intervention, edited by G.M. Lyons and M Mastandono, Baltimore: Johns Hopkins University Press 


\section{Papers}

[65]. Ariffadhillah, Human Rights in Acheh: Implementing the Helsinki Agreements, European Parliament Conference to Discuss Minority Rights and Regional Cooperation in South East Asia, Room PHS7C050 at European Parliament, Brussels, June, 14, 2016

[66]. Dahniar, The State Responsibility for the Gross Violation of Human Rights through the Signature of International Treaty between the Belligerent and the State in the Perspective of National Law and International of Law, Research-result of Dissertation, Decision of the Faculty of Law, No.0335J/H.6.7/Kep/FH/2011, 10 May 2011, Padjadjaran University, West Java, Bandung, Indonesia, 2011.

[67]. ........, The Responsibility of State on the Gross Violation of Human Rights through the Settlement of Non-International Armed Conflict in Aceh in the Perspective of International Law, Research-result of Dissertation, Decision of the Rector Number 1934/2015, 25 November 2015, Syiah Kuala University, Darussalam, Banda Aceh, Indonesia, 2017

[68]. Little, David, Universality of Human Rights, (available at: http://www.usip.org/research /rehr/universality.htm1)

[69]. Sunga, Lyal, S, the United Nations System for Promotion and Protection of Human Rights (with Special Reference to South Korea and the New National Human Rights Commission, 2002

International Documents

[70]. Convention on the Prevention and Punishment of the Crime of Genocide, opened for signature 9 December 1948, 78 UNTS 277, entered into force 12 January 1951

[71]. Convention for the Protection of Human Rights and Fundamental Freedoms, opened for Signature 4 November 1950, 213 UNTS 221, entered into force 3 December 1953

[72]. Convention on the Non-Applicability of Statutory Limitations to War Crimes and Crimes Against Humanity, adopted and opened for signature, ratification and accession by General Assembly Resolution 2391 (XXIII) of 26 November 1968, entered into force on 11 November 1970 (in accordance with article VIII) on the ninetieth day after the date of the deposit with Secretary-General of the United Nations of the tenth instrument of ratification or accession.

[73]. First Optional Protocol to the International Covenant on Civil and Political Rights, opened for signature 16 December 1966, 999 UNTS 171, 301, entered into force 23 March 1976.

[74]. International Covenant on Civil and Political Rights, Art. 2, opened for signature Dec. 16, 1966, S. Exec. Doc. E, 95-2 (1978), 999 U.N.T.S. 171 (entered into force Mar. 23, 1976); id. at S. Treaty Doc. 95-20, 6 I.L.M. 368 (1967)

[75]. ICJ Report, Decision of 11 July 1996 in the case concerning Application of the Convention on the Prevention and Punishment of the Crime of Genocide (Bosnia and Herzegovina v v Yugoslavia), Judgment on Preliminary Objections, 1996.

[76]. ----------, Case concerning the Barcelona Traction, Light and Power Company, Limited Second Phase, Judgment of 5 February, 1970

[77]. International Criminal Law: Quo Vadis? Proceedings of the International Conference held in Siracusa, Italy, 28 November-3 December 2002, on the Occasion of the $30^{\text {th }}$ Anniversary of ISSIC.

[78]. Prosecutor v Erdemovi'c, Case No.IT-96-22-A, Separate and Dissenting. Opinion of Judge Stephen, 25 (International Criminal Tribunal for the Former Yugoslavia, Oct, 7, 1997)

[79]. Optional Protocol to the International Covenant on Economic, Social and Culture Rights, adopted 10 December 2008, UN General Assembly Resolution A/RES/63/117

[80]. Prosecutor v Furund'zija, Case No.IT-95-17/1-T, Judgment (International Criminal Tribunal for the Former Yugoslavia, Dec 10, 1998), www.icty.org/x/cases/furundzija/tjug/en/fur-tj981210e.pdf.

[81]. Responsibility of States for Internationally Wrongful Acts, adopted by the International Law Commission at its fifty-third session, 2001, (extract from the Report of the International Law Commission on the work of its fifty-third session, Official Records of the General Assembly, fifty-sixth session, Supplement No.10 (A/56/10), chp.IV.E.2)

[82]. Rome Statute of the International Criminal Court 1998, Rome Statute circulated as document A/CONF.189/9 of 17 Juli 1998 and corrected by process-verbaux of 10 November 1998, 12 July 1999, 30 November 1999, 8 May 2000, 17 January 2001 and 16 January 2002. The Statute entered into force on 1 July 2002.

[83]. Statute of the international tribunal for the persecution of persons responsibility for serious violations of international humanitarian law committed in the territory of the Former Yugoslavia, (International Criminal for Former Yugoslavia), 1991.

[84]. Statute of the international tribunal for the persecutions of persons responsible for other serious violations of international humanitarian law committed in the territory of the Rwanda and Rwanda citizen 
responsible for genocide and other such violation committed in the territory of neigh boring states between January 1, 1994 and December 31, (International Criminal Tribunal for Rwanda), 1995

[85]. Universal Declaration of Human Rights, drafted by representatives with different legal and cultural background from all regions of the world, the Declaration was proclaimed by the United Nations General Assembly in Paris on 10 December 1948 (General Assembly Resolution 217.A) as a common standard of achievements for all peoples and all nations.

[86]. United Nations Secretary's General, Implementing the Responsibility to Protect (2005, World Summit Outcome), UN. Doc. A/63/677, 12 January 2009, and UN General Assembly Res/63/308, UN Doc, A/Res/63/308, 7 October 2009, Paragraphs 138 and 139

[87]. Unrepresented Nations and Peoples Organization, Alternative Report submitted to the UN Committee on the Economic, Social and Cultural Rights for the consideration of the Second Report of Indonesia during the 52th session, (EC.12/IDN/1), 2014

\section{Acknowledgements}

The first I say thanks to Allah SWT and the Prophet Muhammad SAW; and I, sincerely thanks also to my great father H. Muhammad Dali, S.H.(deceased), for both my lovely mothers Hj.Zulrawiyah and Siti Aminah (deceased), and the parents of my husband H. Martunus (deceased) and Hj.Nurmidar who always guided me through their prayers; also to my honey husband Ded Sinaldi, my wonderful sons Mohammed Thaerieq Phashah, Muhammad Dhaffha Al-Shuffye, who always support me in bad and good situation, include to my big family too. Thanks to the publisher who publishes this paper, also to the person who gave me chance to continue the doctoral program is none other than Governor of Aceh dr. Irwandi Yusuf, M.Sc and former Secretary of Aceh Government Husni Bahri TOB, S.H.,MM.,M.Hum., especially thanks to Dr.Tgk.Hasan Muhammad di Tiro (Wali Nanggroe) and Tgk. Abdullah Syafi'i, Cut Nurasikin, the fighters of Aceh who has fought for the Acehnese human rights 'till his last breaths, I privileged to him for his encouragement. And I would like to thanks my supervisors, Prof. Dr. Adwani, S.H.,M.Hum, Dr. Mujibussalim, S.H.,M.Hum, Dr. Mahfud, S.H.,M.H, who have patiently guided me to finishing my dissertation; I would also like to acknowledgement to the victims of the gross violation of human rights in Aceh, it helping me see the experiences of the families of the disappeared and missing up close, they have given me an important perspective of the complex issues that they face. I would also like to express my gratitude to Tgk. Hasbi Abdullah, dr. Zaini Abdullah, Malek Mahmud, Muzakir Manaf, Azwar Abubakar, Prof. Dr. Lyal S. Sunga, Prof. Dr. Yudha Bhakti A,S.H.,M.H (deceased), Prof. Huala Adolf, S.H., LLM, Ph.D, FCBArb, Prof. Dr. Endang Saefullah, S.H., LLM, Prof. Dr. Edy Damian, LL.M, Dr. Rusli Bintang, Dr. Maida, Yusni Sofyan, SE, Muhammad Dahlan, SE, my best friend Abd Bassir Zomar in Afghanistan, my nice teacher Drs. Iskandar in Caleue-Pidie, and Acheh Sumatra National Liberation Front of members (ASNLF) in all the world for their kind support and assistance.

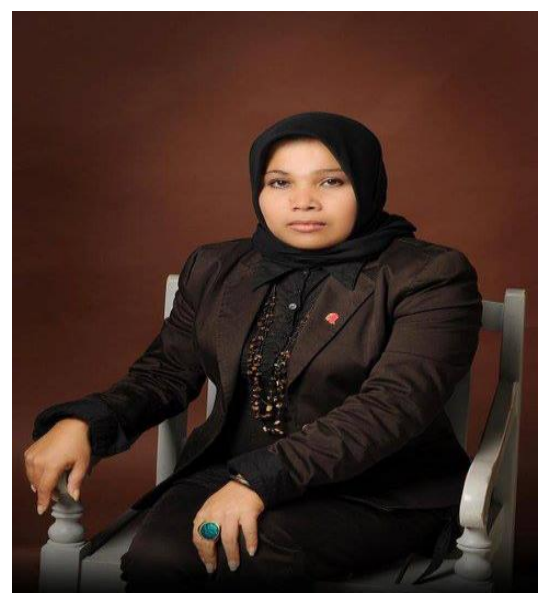

